\title{
Kepastian Hukum dalam Politik Hukum di Indonesia
}

\author{
Fadly Andrianto \\ Fakultas Hukum, Universitas Indonesia, \\ Jalan. Prof. Mr. Djokosoetono, Universitas Indonesia Kampus Depok 16424 \\ Email: fadlyui@gmail.com
}

\begin{abstract}
This study aims to determine the development of legal certainty issues within the scope of law in Indonesia. This research uses normative juridical research methods. The results of the research are that in the discussion of the Second Amendment of the 1945 Constitution of the Republic of Indonesia NRI Article 28I (1) which contains legal certainty is basically proposed based on the political objectives of a particular group and does not answer the issue of legal certainty that actually occurs in Indonesia between positive law and customary law of the Indonesian people. The issue of legal certainty in Indonesia between positive law and customary law of the Indonesian people in its development was then resolved by Law Number 48 of 2009 concerning Judicial Power, namely in Article 5 paragraph (1) and Article 50 paragraph (1). Furthermore, with the enactment of Law Number 6 of 2014 concerning Villages. Current development regarding the issue of legal certainty in Indonesia is in the RUU KUHP.
\end{abstract}

Keywords: Legal Certainty; Positive Law; Customary Law

\begin{abstract}
Abstrak
Penelitian ini bertujuan untuk mengetahui perkembangan isu kepastian hukum dalam ruang lingkup hukum di Indonesia. Penelitian ini menggunakan metode penelitian yuridis normatif. Hasil penelitian yaitu bahwa dalam pembahasan Amandemen Kedua UUD NRI 1945 Pasal 28I ayat (1) yang memuat tentang kepastian hukum pada dasarnya diajukan berdasarkan tujuan politis suatu golongan tertentu dan tidak menjawab mengenai isu kepastian hukum yang sebenarnya terjadi di Indonesia antara hukum positif dan hukum adat masyarakat Indonesia. Isu kepastian hukum di Indonesia antara hukum positif dan hukum adat masyarakat Indonesia dalam perkembangannya kemudian diselesaikan dengan UU Nomor 48 Tahun 2009 tentang Kekuasaan Kehakiman yaitu dalam Pasal 5 ayat (1) dan Pasal 50 ayat (1). Selanjutnya dengan diundangkannya Undang-Undang Nomor 6 Tahun 2014 tentang Desa. Perkembangan saat ini mengenai isu kepastian hukum yang ada di Indonesia yaitu dalam RUU KUHP.
\end{abstract}

Kata Kunci: Kepastian Hukum; Hukum Positif; Hukum Adat 


\section{A. Pendahuluan}

Indonesia sebagai negara civil law system dalam perkembangan hukumnya tidak terlepas dari isu kepastian hukum. Kitab Undang-Undang Hukum Pidana sebagai sumber hukum pidana telah memuat asas legalitas/kepastian hukum yaitu pada Pasal 1 ayat (1), “Tiada suatu perbuatan dapat dipidana kecuali atas kekuatan aturan pidana dalam perundang-undangan yang telah ada, sebelum perbuatan dilakukan.”

Isu kepastian hukum pada awalnya tidak mendapat perhatian khusus dalam perkembangan hukum di Indonesia. Adanya dinamika politik kemudian membawa isu kepastian hukum dalam amandemen kedua UUD NRI 1945. Pasal 28I ayat (1) Amandemen Kedua UUD NRI 1945, yaitu: “... hak untuk tidak dituntut atas dasar hukum yang berlaku surut adalah hak asasi manusia yang tidak dapat dikurangi dalam keadaan apapun.". Apabila ditelusuri lebih jauh, isu kepastian hukum sebenarnya sudah ada sejak Belanda membawa Kitab Undang-Undang Hukum Pidana di Indonesia. Isu kepastian hukum tersebut yaitu antara paham kodifikasi yang dipengaruhi oleh Belanda dan hukum adat atau dikenal juga dengan hukum yang hidup dalam masyarakat Indonesia.

Berkaitan dengan hal tersebut pada kenyataannya amandemen UUD NRI 1945 tidak menjawab mengenai isu kepastian hukum yang sebenarnya terjadi di ruang lingkup hukum positif Indonesia. Perkembangan mengenai isu kepastian hukum di Indonesia antara hukum positif dan hukum adat masyarakat Indonesia kemudian mendapatkan perhatian khusus yaitu dengan diundangkannya beberapa peraturan perundang-undangan dan dalam RUU KUHP.

Berdasarkan uraian latar belakang di atas untuk membatasi pembahasan dalam penelitian ini kemudian diuraikan rumusan permasalahan yaitu: Apa yang mendasari gagasan kepastian hukum dalam Amandemen Kedua UUD NRI 1945?; Bagaimana perkembangan kepastian hukum dalam ruang lingkup hukum adat di Indonesia? Untuk membahasa kedua pertanyaan tersebut saya mengemukakan dua poin bahasan yaitu gagasan kepastian hukum dalam Amandemen Kedua UUD 1945 dan Perkembangan konsep kepastian hukum dalam perkembangan hukum adat di Indonesia. 


\section{B. Pembahasan}

\section{Gagasan Kepastian Hukum dalam Amandemen Kedua UUD NRI 1945}

Gagasan legalitas yang mengklaim dapat memberikan kepastian hukum dalam penegakan hukum khususnya dalam hukum pidana secara historis adalah gagasan yang lahir berkat gagasan legisme L.J. van Apeldoorn, seorang yuris dari Belanda. ${ }^{1}$ Menurut van Apeldorn pengaruh Montesquieu dan lainnya di masa abad ke-19 lahirlah gerakan hukum "legisme", yaitu gerakan isme hukum yang mengasumsikan bahwa setiap kegiatan penerapan hukum, itu semata-mata hanyalah suatu penerapan isi dari undang-undang terhadap perkara-perkara konkret. Penerapan ini dilaksanakan secara rasional dan logis. Itu disebabkan undang-undang dianggap sebagai suatu sistem yang logis, yang bisa diberlakukan terhadap setiap perkara. ${ }^{2}$ Sehingga kepastian hukum yang diberikan oleh legalitas tidak boleh dipandang terputus dengan legisme. Keduanya sama-sama menjadi peletak atau fondasi dasar dari kepastian hukum yang tertuang dalam hukum (undang-undang). ${ }^{3}$

Gagasan legalitas di Indonesia sudah ada sejak Kitab Undang-Undang Hukum Pidana (KUHP) didatangkan oleh Belanda yang kemudian diterima dalam sistem hukum di Indonesia. Kemudian gagasan legalitas ini diusulkan oleh dalam proposal amandemen UUD NRI 1945 yang dilaksanakan pasca-pemilu 1999. Kemunculan proposal ini dilatari oleh motif politis dari kelompok ABRI untuk melindungi kelompoknya dari peradilan hak asasi manusia. ${ }^{4}$ Pasal 28I ayat (1) Amandemen Kedua UUD NRI 1945, yaitu:

“... hak untuk tidak dituntut atas dasar hukum yang berlaku surut adalah hak asasi manusia yang tidak dapat dikurangi dalam keadaan apapun."

Sebelumnya, gagasan legalitas ini tidak pernah dibahas dalam ruang lingkup hukum di Indonesia. Ia dimasukkan dengan harapan dapat menjadi obat mujarab

\footnotetext{
${ }^{1}$ E. Fernando M. Manullang, Legisme, Legalitas dan Kepastian Hukum, (Jakarta: Kencana, 2017), hlm. 9 .

${ }^{2}$ Ibid, hlm. 14.

${ }^{3}$ Ibid, hlm. 14-15.

${ }^{4}$ Denny Indrayana, Amandemen UUD 1945, hlm. 234-237 dalam E. Fernando M. Manullang, Legisme, Legalitas dan Kepastian Hukum. Ibid, hlm. 7.
} 
terhadap ketidakpastian hukum dalam penegakan hukum, khususnya yang dirasakan oleh banyak orang di masa pemerintahan Presiden Soeharto (Orde Baru). ${ }^{5}$

Penulis melihat munculnya Pasal 28I ayat (1) Amandemen Kedua UUD NRI 1945 yang diusulkan oleh kelompok ABRI bukanlah suatu jawaban atas gagasan legalitas di Indonesia. Fakta bahwa hal tersebut didasari oleh kelompok ABRI yang ingin melindungi kelompoknya terhadap kegiatan operasi ABRI pada masa Orde Baru dari peradilan HAM menunjukkan bahwa gagasan tersebut tidaklah tepat dianggap sebagai gagasan legalitas yang selama ini dimaksudkan sebagai asas kepastian hukum. Hal ini kemudian menjadi kontras ketika tujuan proposal ini ternyata gagal dikemudian hari setelah adanya pengadilan HAM yang berlaku hukum secara surut.

Munculnya gagasan legalitas di Indonesia apabila dibandingkan dengan lahirnya Teori Kepastian Hukum yang dikemukakan oleh Gustav Radbruch sangat jauh berbeda. Teori Kepastian Hukum muncul ketika tidak adanya demokrasi dan timbulah kesewenangan pada masa Nazi Jerman sedangkan di Indonesia muncul bukan karena permasalahan bidang hukum di Indonesia secara menyeluruh melainkan muncul atas kepentingan kelompok tertentu.

Menurut penulis, permasalahan gagasan legalitas muncul semenjak adanya asas legalitas dan paham kodifikasi yang dibawa oleh Belanda pada masa penjajahan di Indonesia yaitu antara KUHP dengan Hukum Adat yang hidup dalam masyarakat Indonesia. Permasalahan tersebut terjadi karena selama ini sebelum Belanda masuk di Indonesia, masyarakat Indonesia dalam menjalankan hukum didasari oleh hukum adat yang diakui oleh masyarakat. Hukum adat tersebut tidak tertulis akan tetapi diakui keberadaannya dan berlaku bagi masyarakat adat tertentu. Akan tetapi hanya sedikit akademisi hukum pada masa itu membahas mengenai permasalahan ini dan dalam tingkat pemerintahan dan parlemenpun tidak pernah menganggap gagasan legalitas sebagai suatu hal yang penting dan mendesak. Hal ini dibuktikan dengan tujuan diusulkannya proposal amandemen UUD NRI 1945 Pasal 28I ayat (1) atas dasar motif

${ }^{5}$ Loc.cit. 
politis, bukan karena atas dasar permasalahan hukum yang selama ini nyata ada dalam permasalahan hukum di Indonesia.

\section{Perkembangan Kepastian Hukum dalam Ruang Lingkup Hukum Adat di Indonesia}

Setelah Belanda datang ke Indonesia dan membawa pengaruh khususnya dalam bidang hukum maka munculah doktrin hukum dalam masyarakat Indonesia yaitu hukum yang berlaku adalah hukum yang tertulis. Doktrin tersebut menjadi awal mula gagasan legalitas lahir di Indonesia dan bertahan hingga pada masa sekarang.

Dalam perkembangan hukum setelah Indonesia merdeka, hukum adat sebenarnya diakui dalam sistem hukum di Indonesia. Pengakuan akan hukum adat ini terdapat dalam Pasal 18B ayat (2) UUD NRI 1945, yaitu:

"Negara mengakui dan menghormati kesatuan-kesatuan masyarakat hukum adat beserta hak-hak tradisionalnya sepanjang masih hidup dan sesuai dengan perkembangan masyarakat dan prinsip Negara Kesatuan Republik Indonesia, yang diatur dalam undang-undang."

Akan tetapi Pasal 18B ayat (2) UUD NRI 1945 belum menjawab mengenai permasalahan antara hukum positif di Indonesia dan hukum yang hidup di masyarakat atau hukum adat. Lembaga Yudisial di Indonesia kemudian berusaha untuk menyelesaikan permasalahan ini sehingga diundangkannya UU Nomor 48 Tahun 2009 tentang Kekuasaan Kehakiman. Pasal 5 ayat (1) Undang-Undang Nomor 48 Tahun 2009 tentang Kekuasaan Kehakiman menjelaskan bahwa dalam memutus perkara seorang hakim wajib menggali, mengikuti, dan memahami nilai-nilai hukum dan rasa keadilan yang hidup dalam masyarakat. Pasal 50 ayat (1) menjelaskan bahwa putusan pengadilan selain harus memuat alasan dan dasar putusan, juga memuat pasal tertentu dari peraturan perundang-undangan bersangkutan atau sumber hukum tak tertulis yang dijadikan dasar untuk mengadili.

Kemudian diundangkan juga Undang-Undang Nomor 6 Tahun 2014 tentang Desa yang mengakui adanya Peraturan Desa Adat dalam Pasal 110, bahwa "Peraturan Desa Adat disesuaikan dengan hukum adat dan norma adat istiadat yang berlaku di 
Desa Adat sepanjang tidak bertentangan dengan ketentuan peraturan perundangundangan". Pasal 111 ayat (1) menjelaskan bahwa ketentuan tersebut hanya berlaku bagi desa adat.

Dalam Rancangan KUHP gagasan legalitas ada dua macam yaitu asas legalitas secara formil dan secara materiil. Asas legalitas formil diatur dalam Pasal 1 ayat (1) RUU KUHP. Pasal tersebut berbunyi: "tiada seorang pun dapat dipidana atau dikenakan tindakan, kecuali perbuatan yang dilakukan telah ditetapkan sebagai tindak pidana dalam peraturan perundang-undangan yang berlaku pada saat perbuatan itu dilakukan”. Bunyi pasal ini sebenarnya masih seirama dengan asas legalitas yang berlaku saat ini. ${ }^{6}$

Asas legalitas materil kemudian diatur secara khusus dan eksplisit dalam Pasal 2 RUU KUHP. Pasal 2 ayat (1) berbunyi: "ketentuan sebagaimana dimaksud dalam Pasal 1 ayat (1) tidak mengurangi berlakunya hukum yang hidup dalam masyarakat yang menentukan bahwa seseorang patut dipidana walaupun perbuatan tersebut tidak diatur dalam peraturan. perundang-undangan". Pasal inilah yang telah membuka keberlakuan "hukum yang hidup di masyarakat" (the living law). Dengan kata lain, seseorang dapat dipidana berdasarkan hukum yang hidup di masyarakat, meskipun undangundang tidak menentukan secara eksplisit bahwa perbuatan tersebut sebagai perbuatan pidana. $^{7}$

Kemudian dalam Pasal 2 ayat (2) RUU KUHP ditentukan pula bahwa "berlakunya hukum yang hidup dalam masyarakat sebagaimana dimaksud pada ayat (1) sepanjang sesuai dengan nilai-nilai yang terkandung dalam Pancasila, hak asasi manusia, dan prinsip-prinsip hukum umum yang diakui oleh masyarakat bangsabangsa". Ayat ini bermaksud menentukan batasan terhadap "hukum yang hidup di masyarakat" tersebut. Namun, makna "hukum yang hidup di masyarakat" masih

\footnotetext{
${ }^{6}$ Prianter Jaya Hairi, Kontradiksi Pengaturan “Hukum Yang Hidup Di Masyarakat” Sebagai Bagian Dari Asas Legalitas Hukum Pidana Indonesia, (Jakarta: Pusat Penelitian Badan Keahlian DPR RI, 2016). Jurnal Negara Hukum: Vol. 7, No. 1, Juni 2016. hlm 90.

${ }^{7}$ Loc.cit.
} 
memiliki cakupan yang sangat luas, termasuk hukum adat, kebiasaan, dan hukum lokal atau hukum agama, seperti: hukum syariat Islam di Aceh. ${ }^{8}$

Rancangan KUHP tersebut tidak terlepas dari Teori Hukum Progresif yang dikemukakan oleh Prof. Satjipto Raharjo. Gagasan hukum progresif muncul sebagai reaksi keprihatinan terhadap keadaan hukum di Indonesia, sehingga muncul pendapat dari pengamat internasional hingga masyarakat awam bahwa sistem hukum Indonesia masih jauh dari harapan dan memerlukan pembenahan secara serius. Gagasan hukum progresif muncul sebagai reaksi atas "kegagalan” hukum Indonesia yang didominasi doktrin positivism dalam menanggulangi kasus-kasus korupsi dan pelanggaran hak asasi manusia. $^{9}$

Menurut Satjipto Rahardjo, ada beberapa kata kunci pada pemikiran hukum progresif, yaitu: ${ }^{10}$

1. Hukum progresif itu untuk manusia, bukan manusia untuk hukum. Pada hakikatnya setiap manusia itu baik, sehingga sifat ini layak menjadi modal dalam membangun kehidupan berhukumnya. Hukum bukan raja (segalanya), tetapi sekadar alat bagi manusia untuk memberi rahmat kepada dunia dan kemanusiaan.

2. Hukum progresif itu harus pro-rakyat dan pro-keadilan. Hukum itu harus berpihak kepada rakyat. Keadilan harus didudukkan di atas peraturan. Para penegak hukum harus berani menerobos kekakuan teks peraturan (diistilahkan sebagai "mobilisasi hukum") jika memang teks itu mencederai rasa keadilan rakyat.

3. Hukum progresif selalu dalam proses menjadi (law as a process, law in the making). Hukum bukan institusi yang final, melainkan ditentukan oleh kemampuannya mengabdi kepada manusia. Ia terus-menerus membangun dan mengubah dirinya menuju kepada tingkat kesempurnaan yang lebih baik.

\footnotetext{
${ }^{8}$ Loc.cit.

${ }^{9}$ Prianter Jaya Hairi. Ibid, hlm. 93.

${ }^{10}$ Satijpto Rahardjo, Hukum Progresif: Aksi, Bukan Teks, dalam Satya Arinanto \& Ninuk Triyanto, ed., Memahami Hukum: dari Konstruksi sampai Implementasi, Jakarta: Rajawali Pers, 2009, hlm. 17, 46-48.
} 
4. Hukum progresif memiliki tipe responsif. Dalam tipe responsif, hukum akan selalu dikaitkan pada tujuan-tujuan di luar narasi tekstual hukum itu sendiri, yang disebut oleh Nonet dan Selznick sebagai "the souverignity of purpose".

5. Hukum progresif itu merobohkan, mengganti, dan membebaskan. Hukum progresif menolak sikap status quo dan submisif. Sikap status quo menyebabkan kita tidak berani melakukan perubahan dan menganggap doktrin sebagai sesuatu yang mutlak untuk dilaksanakan. Sikap demikian hanya merujuk kepada maksim "rakyat untuk hukum".

Dengan demikian, menjalankan hukum secara progresif tidak semata-mata berpijak pada rule and logic namun juga rule and behavior. Hal ini mengingatkan pada penyataan Oliver Wendell Holmes: “...The live of the law has not been logic. It has been experience". Menggunakan hukum tidak semata-mata mengandalkan logika peraturan namun juga harus mempertimbangkan hukum yang bersumber dari pengalaman empiris misalnya kearifan lokal. ${ }^{11}$

Berdasarkan hal tersebut penulis sependapat dengan Teori Hukum Progresif dalam pembaharuan Rancangan KUHP termasuk mengenai konsep gagasan legalitas formil dan materiil. Bahwa peraturan perundang-undangan menurut penulis tidak semata-mata menjadi sebuah rule atau aturan main. Aturan main tersebut tidak boleh dipandang hanya sebagai wujud dari kepastian hukum.

Berkaitan dengan hal tersebut di atas Penulis sependapat dengan aliran sosiologi hukum oleh Oliver W. Holmes yang menyatakan bahwa, "the prophecies of what the courts will do in fact, and nothing more pretentious, are what I mean by the law". ${ }^{12}$ Yaitu hukum adalah apa yang ada dalam pengadilan. Berkaitan dengan hal tersebut dalam Pasal 55A Rancangan KUHP bahwa, "Hakim dalam mengadili suatu perkara pidana wajib menegakkan hukum dan keadilan". Sehingga antara aliran realism oleh Oliver W. Holmes dikaitkan dengan Teori Hukum Progresif yang ada dalam Rancangan KUHP dapat dikatakan bahwa keduanya memiliki pemikiran yang sama yaitu undang-undang sebagai hukum yang tertulis yang dianggap sebagai kepastian

${ }^{11}$ Al. Wisnubroto, dalam Prianter Jaya Hairi. Ibid., hlm. 95.

${ }^{12}$ Steven Vago and Steven E. Barkan, Law and Society, Eleventh edition, (New York: Routledge 2018) 
hukum di Indonesia seharusnya tidak menjadi suatu halangan dalam menegakkan keadilan. Undang-undang hanyalah sebagai aturan main sedangkan yang menentukan keadilan adalah hakim sehingga keadilan di atas dari gagasan legalitas.

Dengan demikian Penulis sependapat dengan Teori Tiga Nilai Dasar Hukum yang dikemukakan oleh Gustav Radbruch dalam bukunya yang berjudul Rechtsphilosophie tahun 1975 yang mengatakan bahwa yang paling utama dari teorinya adalah keadilan dan kemanfaatan setelah itu baru kepastian hukum dapat tercapai. Menurut Gustav Radbruch apabila memperbincangkan kepastian hukum tidak hanya semata-mata tentang tujuan hukum akan tetapi juga suasana (suasana pengadilan, hakim, dll), HAM, dan demokrasi.

Penulis berpendapat bahwa kepastian hukum tidaklah sama dengan keadilan. Kepastian hukum akan memunculkan keadilan dan keadilan adalah ketika adanya suatu kepastian hukum.

\section{Simpulan}

Pembahasan Amandemen Kedua UUD NRI 1945 Pasal 28I (1) yang memuat tentang kepastian hukum pada dasarnya diajukan berdasarkan tujuan politis suatu golongan tertentu dan tidak menjawab mengenai isu kepastian hukum yang sebenarnya terjadi di Indonesia antara hukum positif dan hukum adat masyarakat Indonesia. Isu kepastian hukum di Indonesia antara hukum positif dan hukum adat masyarakat Indonesia dalam perkembangannya diselesaikan dengan adanya UU Nomor 48 Tahun 2009 tentang Kekuasaan Kehakiman yaitu dalam Pasal 5 ayat (1) bahwa dalam memutus perkara seorang hakim wajib menggali, mengikuti, dan memahami nilai-nilai hukum dan rasa keadilan yang hidup dalam masyarakat; dan Pasal 50 ayat (1) bahwa putusan pengadilan selain harus memuat alasan dan dasar putusan, juga memuat pasal tertentu dari peraturan perundang-undangan bersangkutan atau sumber hukum tak tertulis yang dijadikan dasar untuk mengadili. Selanjutnya dengan diundangkannya Undang-Undang Nomor 6 Tahun 2014 tentang Desa yaitu dalam Pasal 110, bahwa Peraturan Desa Adat disesuaikan dengan hukum adat dan norma adat istiadat yang berlaku di Desa Adat sepanjang tidak bertentangan dengan 
ketentuan peraturan perundang-undangan. Pasal 111 ayat (1) menjelaskan bahwa ketentuan tersebut hanya berlaku bagi desa adat. Perkembangan terakhir mengenai isu kepastian hukum yang ada di Indonesia yaitu dalam RUU KUHP, Pasal 2 ayat (1) berbunyi: "ketentuan sebagaimana dimaksud dalam Pasal 1 ayat (1) tidak mengurangi berlakunya hukum yang hidup dalam masyarakat yang menentukan bahwa seseorang patut dipidana walaupun perbuatan tersebut tidak diatur dalam peraturan. perundangundangan". Pasal inilah yang telah membuka keberlakuan "hukum yang hidup di masyarakat" (the living law).

\section{Daftar Pustaka}

E. Fernando M. Manullang. (2017). Legisme, Legalitas dan Kepastian Hukum. Jakarta: Kencana.

Gustav Radbruch. (1975). Rechtsphilosophie. Stuttgart: K.F. Koehler Verlag.

Prianter Jaya Hairi. (2016). Kontradiksi Pengaturan "Hukum Yang Hidup Di Masyarakat” Sebagai Bagian Dari Asas Legalitas Hukum Pidana Indonesia. (Jakarta: Pusat Penelitian Badan Keahlian DPR RI, 2016). Jurnal Negara Hukum: Vol. 7, No. 1, Juni.

Satjipto Rahardjo. (2009). Hukum Progresif: Aksi, Bukan Teks, dalam Satya Arinanto \& Ninuk Triyanto, ed., Memahami Hukum: dari Konstruksi sampai Implementasi. Jakarta: Rajawali Pers.

Steven Vago and Steven E. Barkan. (2018). Law and Society. Eleventh edition. New York: Routledge. 